\title{
The impact of climate change and sowing time on the yield and quality of maize (Zea mays L.)
}

Adrienn SZÉLES - Éva HORVÁTH - János NAGY

Institute for Land Utilisation, Regional Development and Technology, Faculty of Agricultural and Food Sciences and Environmental Management, University of Debrecen; E-mail: szelesa@agr.unideb.hu

Keywords: environmental factor, sowing date, genotype, quality

\section{Introduction}

Climate change is challenging the world's agricultural production in several fields (Jolánkai \& Birkás, 2009; Godfray et al., 2010; Pepó, 2015). Arid and rainy periods are more common, the probability for the occurrence of extreme weather conditions and the strength of their impact are increasing even within one year or growing season. The situation is further enhanced by the fact that within 15 years the population of the Earth is going to increase from seven to eight billion. Feeding the world's population inevitably requires raising the production (Sheng-mao et al., 2006).

The research is aiming at examining those abiotic factors which can be crucially important from the aspect of plant production and quality (starch, protein and oil content).

\section{Materials and methods}

The examinations were carried out at the Látókép Experimental Site of the Centre for Agricultural and Applied Economic Sciences of the University of Debrecen in Eastern Hungary (N: 4733', E: 21 ${ }^{\circ} 26^{\prime}, 111$ metres above sea level) in a moderately warm and dry production area on loess-based mid-heavy calcareous chernozem soil with deep humus layer in a small plot field experiment with a strip plot experimental design and four replications.

In the two experimental years, we evaluated the effect of the sowing date (early sowing: 18 days before the optimal sowing date ( $23^{\text {rd }}$ April); late sowing: 17 days after the optimal date) and the environmental factors (2011 was wet and 2014 had average precipitation supply) on the yield and grain quality parameters (starch, protein and oil content) of four different FAO maize hybrids (FAO 290, FAO 370, FAO 420 and FAO 500).

\section{Results and discussion}

Based on the examination results, it can be stated that the sowing date has the most significant effect, as it affects the yield quantity $(\mathrm{P}<0.01)$, as well as the grain protein $(\mathrm{P}<0.001)$, starch $(\mathrm{P}<0.001)$ and oil content $(\mathrm{P}<0.001)$. As regards the quality parameters and yield, there were significant differences between hybrids. The grain protein and oil content was smaller and the starch content was higher in 2014 (wet year) than in 2011, when the weather was favourable, although the environmental factor significantly affected the oil content $(\mathrm{P}<0.05)$ and it had no effect on the protein and starch content.

From the aspect of starch content, the early sowing date (6th April, Figure 1) was shown to be the most favourable, while the late sowing date (10th May) showed the best results 
in both years concerning protein and oil content The FAO 420 maize hybrid had higher starch content, while the FAO 290 hybrid had higher protein and oil content.

The maize hybrid yields were different in both examined years. The average yield of the four hybrids was $9.517 \mathrm{t} \mathrm{ha}^{-1}$ in 2014 and $10.332 \mathrm{t} \mathrm{ha}^{-1}$ in 2011 which shows $0.815 \mathrm{t} \mathrm{ha}^{-1}$ yield fluctuation. Of the examined hybrids, the FAO 500 hybrid had the highest yield in both years.

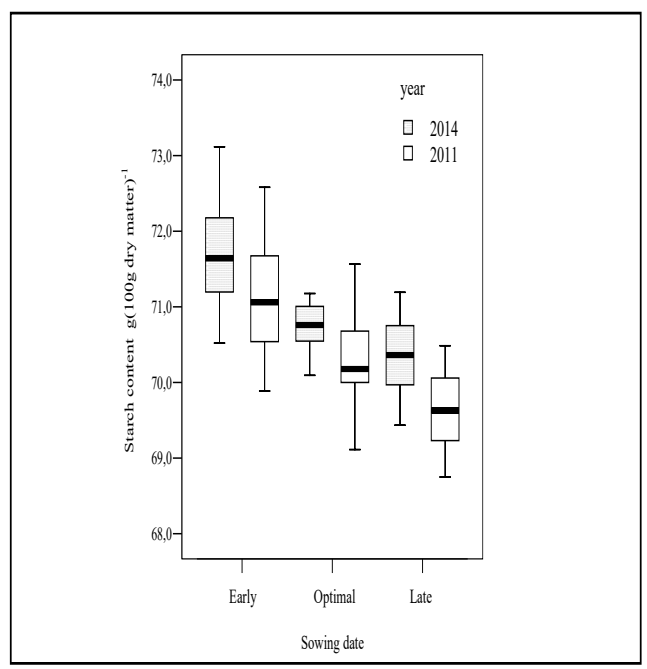

Figure 1: The effect of sowing date on the grain starch content

\section{Conclusions}

Choosing the optimal sowing date is crucial in maize yield and in adapting to the changing circumstances. The results of the experiment show that grain yield determined the starch, protein and oil yield per hectare.

\section{Acknowledgement}

The research was financed by the Higher Education Institutional Excellence Programme of the Ministry of Human Capacities in Hungary, within the framework of the 4.thematic programme of the University of Debrecen, and the projects "GINOP-2.2.1-15-2016-00001

- Developing a scale-independent complex precision consultancy system" and "EFOP3.6.3-VEKOP-16-2017-00008”.

\section{References}

Godfray H.C.J., Beddington J.R., Crute I.R., Haddad L., Lawrence D., Muir J.F., Pretty J., Robinson S., Thomas S.M., Toulmin C. (2010): Food security: The challenge of feeding 9 billion people. Science. 327(5967): 812818. https://doi.org/10.1126/science. 1185383

Jolánkai M., Birkás M. (2009): Climate change and water availability in the agro-ecosystems of Hungary. Pollution and Water Resources-Columbia University Seminar Series. 38-39: 171-180.

Pepó P. (2015): Effects of climate change in cereals production in long-term experiments. Növénytermelés. 64:(Suppl2.) 155-164.

Sheng-mao Y., Feng-min L., Dong-rang S., Tian-wen G., Jian-guo W., Bing-ling S., Shao-ling J. (2006): Effect of Long-Term Fertilization on Soil Productivity and Nitrate Accumulation in Gansu Oasis. Agricultural Sciences in China. 5: 1. 57-67. https://doi.org/10.1016/s1671-2927(06)60020-5 